Prepared in cooperation with the West Virginia Department of Environmental Protection, Division of Water and Waste Management

\title{
Comparison of Base Flows to Selected Streamflow Statistics Representative of 1930-2002 in West Virginia
}

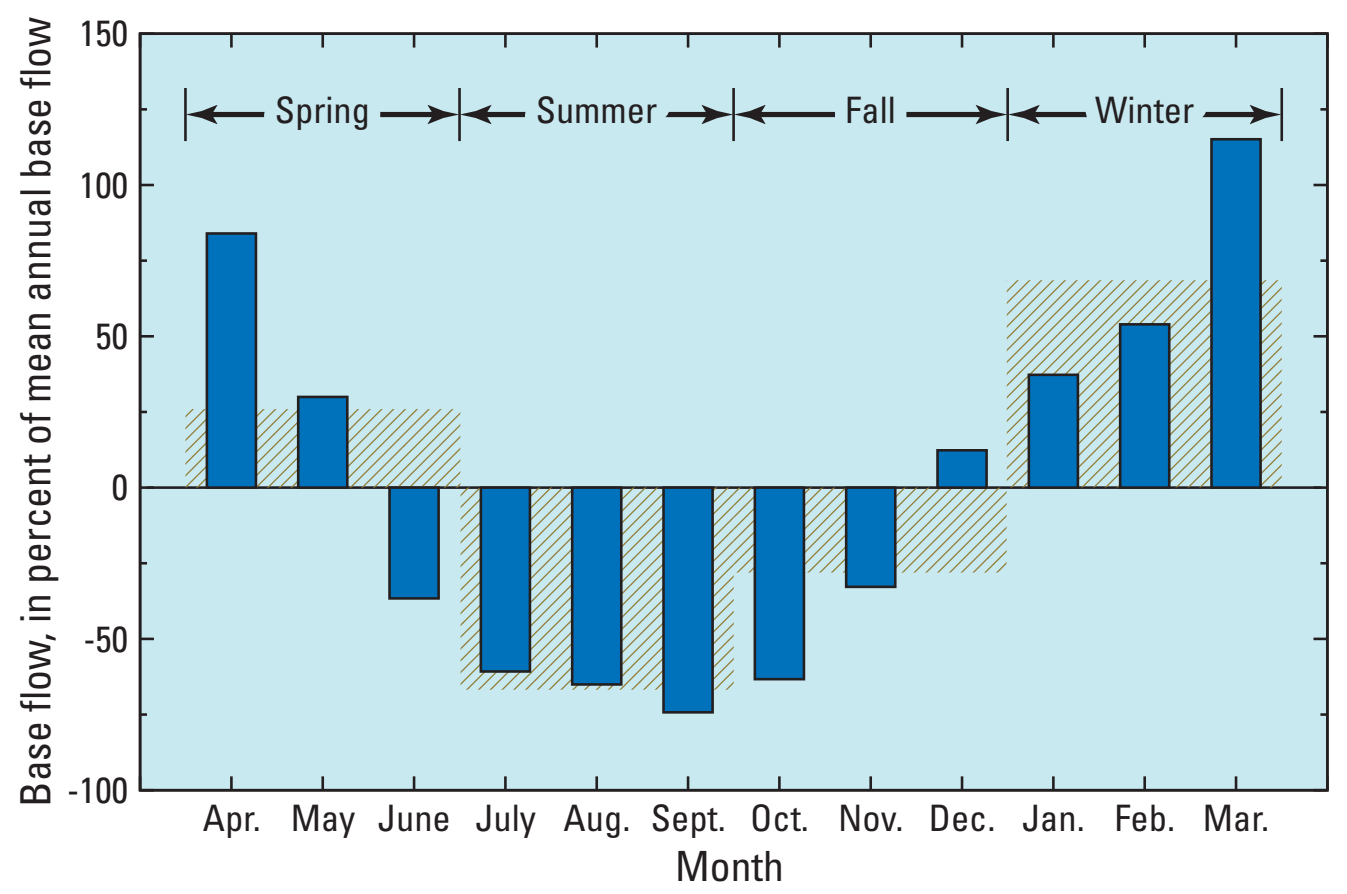

Scientific Investigations Report 2012-5121 
Cover. Mean seasonal and mean monthly base flows as percentage of mean annual base flows for 15 streamflow-gaging stations in West Virginia, 1930-2002. 


\section{Comparison of Base Flows to Selected Streamflow Statistics Representative of 1930-2002 in West Virginia}

By Jeffrey B. Wiley

Prepared in cooperation with

the West Virginia Department of Environmental Protection,

Division of Water and Waste Management

Scientific Investigations Report 2012-5121 


\title{
U.S. Department of the Interior \\ KEN SALAZAR, Secretary \\ U.S. Geological Survey \\ Marcia K. McNutt, Director
}

\author{
U.S. Geological Survey, Reston, Virginia: 2012
}

For more information on the USGS - the Federal source for science about the Earth, its natural and living resources, natural hazards, and the environment, visit http://www.usgs.gov or call 1-888-ASK-USGS.

For an overview of USGS information products, including maps, imagery, and publications, visit http://www.usgs.gov/pubprod

To order this and other USGS information products, visit http://store.usgs.gov

Any use of trade, product, or firm names is for descriptive purposes only and does not imply endorsement by the U.S. Government.

Although this report is in the public domain, permission must be secured from the individual copyright owners to reproduce any copyrighted materials contained within this report.

Suggested citation:

Wiley, J.B., 2012, Comparison of base flows to selected streamflow statistics representative of 1930-2002 in West Virginia: U.S. Geological Survey Scientific Investigations Report 2012-5121, 18 p. 


\section{Acknowledgments}

The author thanks U.S. Geological Survey colleague Samuel H. Austin and U.S. Fish and Wildlife Service colleague Rachel A. Esralew for their technical reviews of this report. The technical assistance of colleagues Terence Messinger and Katherine S. Paybins and editorial assistance of Ruth Larkins also are appreciated. 


\section{Contents}

Acknowledgments .......................................................................................................................

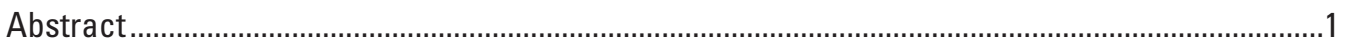

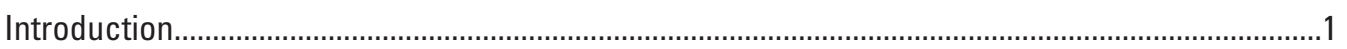

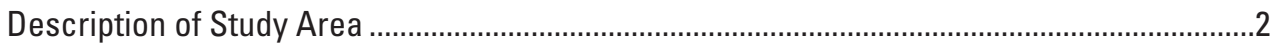

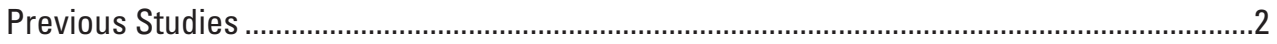

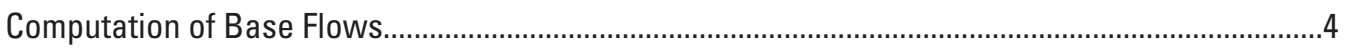

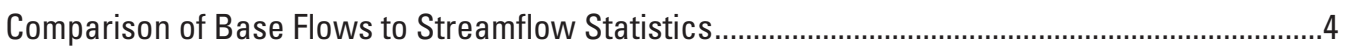

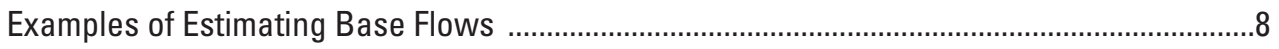

Limitations of Base-Flow Estimates....................................................................................11

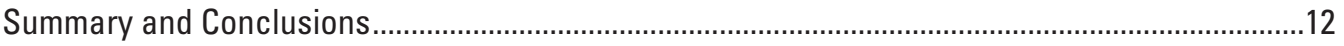

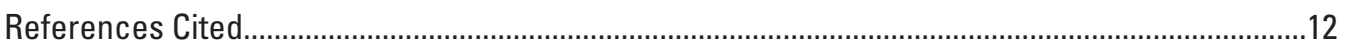

Appendix 1. Annual and seasonal base flows at 15 streamflow-gaging stations

in West Virginia, 1930-2002 .......................................................................................

\section{Figures}

1. Map showing Appalachian Plateaus, Valley and Ridge, and Blue Ridge

Physiographic Provinces, and Climatic Divide in West Virginia

2. Map showing location of selected U.S. Geological Survey streamflow-gaging stations in West Virginia.

3. Graph showing mean seasonal and mean monthly base flows as percentage of mean annual base flows for 15 streamflow-gaging stations in West Virginia, 1930-2002.

4. Graph showing mean annual base flows in relation to annual 50-percent duration flows for 15 streamflow-gaging stations in West Virginia, 1930-2002.

5. Graphs showing mean seasonal and mean annual base flows in relation to selected duration flows for 15 streamflow-gaging stations during $A$, spring, $B$, summer, $C$, fall, and $D$, winter in West Virginia, 1930-2002.

\section{Tables}

1. The streamflow-gaging stations used to compare base flows and selected streamflow statistics in West Virginia.

2. Average, minimum, and maximum differences between mean annual base flows and selected annual statistics computed for 1930-2002, and those computed for the indicated record periods for 15 streamflow-gaging stations in West Virginia

3. Average differences between base flows and selected seasonal statistics computed for 1930-2002, and those computed for the indicated record periods for 15 streamflow-gaging stations in West Virginia 


\section{Conversion Factors and Datums}

\begin{tabular}{lcl}
\hline \multicolumn{1}{c}{ Multiply } & By & \multicolumn{1}{c}{ To obtain } \\
\hline & Length & \\
\hline inch (in.) & 2.54 & centimeter $(\mathrm{cm})$ \\
inch (in.) & 25.4 & millimeter $(\mathrm{mm})$ \\
foot (ft) & 0.3048 & meter $(\mathrm{m})$ \\
mile (mi) & 1.609 & kilometer $(\mathrm{km})$ \\
\hline \multicolumn{3}{c}{ Area } \\
\hline acre & 4,047 & \\
square foot $\left(\mathrm{ft}^{2}\right)$ & 0.09290 & square meter $\left(\mathrm{m}^{2}\right)$ \\
square mile $\left(\mathrm{mi}^{2}\right)$ & 2.590 & square meter $\left(\mathrm{m}^{2}\right)$ \\
\hline & Volume & \\
\hline cubic foot $\left(\mathrm{ft}^{3}\right)$ & 0.02832 & cubic meter $\left(\mathrm{m}^{3}\right)$ \\
\hline & Flow rate & \\
\hline cubic foot per second $\left(\mathrm{ft}^{3} / \mathrm{s}\right)$ & 0.02832 & cubic meter per second $\left(\mathrm{m}^{3} / \mathrm{s}\right)$ \\
\hline
\end{tabular}

Vertical coordinate information is referenced to the North American Vertical Datum of 1988 (NAVD 88).

Horizontal coordinate information is referenced to the North American Datum of 1983 (NAD 83).

Altitude, as used in this report, refers to distance above the vertical datum. 


\section{Comparison of Base Flows to Selected Streamflow Statistics Representative of 1930-2002 in West Virginia}

By Jeffrey B. Wiley

\section{Abstract}

Base flows were compared with published streamflow statistics to assess climate variability and to determine the published statistics that can be substituted for annual and seasonal base flows of unregulated streams in West Virginia. The comparison study was done by the U.S. Geological Survey, in cooperation with the West Virginia Department of Environmental Protection, Division of Water and Waste Management. The seasons were defined as winter (January 1-March 31), spring (April 1-June 30), summer (July 1-September 30), and fall (October 1-December 31).

Differences in mean annual base flows for five record sub-periods (1930-42, 1943-62, 1963-69, 1970-79, and 1980-2002) range from -14.9 to 14.6 percent when compared to the values for the period 1930-2002. Differences between mean seasonal base flows and values for the period 19302002 are less variable for winter and spring, -11.2 to 11.0 percent, than for summer and fall, -47.0 to 43.6 percent. Mean summer base flows (July-September) and mean monthly base flows for July, August, September, and October are approximately equal, within 7.4 percentage points of mean annual base flow. The mean of each of annual, spring, summer, fall, and winter base flows are approximately equal to the annual 50-percent (standard error of 10.3 percent), 45-percent (error of 14.6 percent), 75-percent (error of 11.8 percent), 55-percent (error of 11.2 percent), and 35-percent duration flows (error of 11.1 percent), respectively. The mean seasonal base flows for spring, summer, fall, and winter are approximately equal to the spring 50- to 55-percent (standard error of 6.8 percent), summer 45 - to 50 -percent (error of 6.7 percent), fall 45-percent (error of 15.2 percent), and winter 60-percent duration flows (error of 8.5 percent), respectively.

Annual and seasonal base flows representative of the period 1930-2002 at unregulated streamflow-gaging stations and ungaged locations in West Virginia can be estimated using previously published values of statistics and procedures.

\section{Introduction}

Streamflow can be separated into discharge from overland runoff and discharge from groundwater. Base flow is the portion of streamflow contributed by groundwater discharge. Generally, base flows are greater in wetter seasons than in dryer seasons because more water accumulates and is released from groundwater. Knowledge of climatic, seasonal, and monthly differences in base flows can assist scientists and water-resource managers in understanding the capacity of groundwater storage in watersheds and the ability of a stream to maintain flows during droughts.

Streamflow statistics have been computed for streamflow-gaging stations, and equations have been determined to estimate streamflows at ungaged locations in West Virginia for the period 1930 to 2002 (Wiley, 2006, 2008; Wiley and Atkins, 2010a). Equations for estimating base flows could be determined using similar methods, but a simpler and lower cost method for estimating base flows is already available if published streamflow statistics can be used as surrogates for base flows.

This study, conducted in cooperation with the West Virginia Department of Environmental Protection, Division of Waste and Water Management, investigated the climatic, seasonal, and monthly variability of base flows at 15 selected long-term streamflow-gaging stations, documented the development of relations between base flows and published streamflow statistics, and determined surrogate statistics (the published statistics that can be substituted for base flows) to be used to estimate annual and seasonal base flows at other streamflow-gaging stations and at ungaged locations. The results of this study are representative of the period 1930-2002 and are relevant only to West Virginia, but the procedures presented in this report can be used to determine substitute streamflow statistics that can be used to estimate base flows in other regions.

This report presents the procedures used to estimate base flows for 1930-2002. The climatic, seasonal, and monthly 
variability of base flows at 15 long-term streamflow-gaging stations is discussed. Relations between mean annual and mean seasonal base flows, and between mean annual and 50 -percent duration flows, are shown in illustrations. Relations between mean seasonal base flows and seasonal duration flows are also shown in illustrations. Differences between mean annual base flows and annual streamflow statistics are listed in tables. Base flows for the 15 long-term streamflow-gaging stations are provided in an Appendix as supplementary information.

\section{Description of Study Area}

West Virginia can be differentiated into three physiographic provinces (fig. 1), the Appalachian Plateaus, Valley and Ridge, and Blue Ridge (Fenneman, 1938). The movement of air masses across the State allows identification of two climatic regions (fig. 1), separated by a line defined as the Climatic Divide (Wiley and others, 2000; Wiley and Atkins, 2010b).

Generally, the part of the State west of the Climatic Divide is in the Appalachian Plateaus Physiographic Province; altitudes in the Appalachian Plateaus range from about 2,500 to $4,861 \mathrm{ft}$ (NAVD 88) at Spruce Knob along the Climatic Divide to about 550 to $650 \mathrm{ft}$ along the Ohio River. The part of West Virginia east of the Climatic Divide is in the Valley and Ridge Physiographic Province, except for the extreme eastern tip of the State, which is in the Blue Ridge Physiographic Province. Altitudes decrease eastward from the Climatic Divide to $274 \mathrm{ft}$ at Harpers Ferry in the Eastern Panhandle (U.S. Geological Survey, 1990, 2006; National Oceanic and Atmospheric Administration, 2006a).

The Appalachian Plateaus Physiographic Province consists of consolidated, mostly siliciclastic sedimentary rocks that have a gentle slope from southeast to northwest near the Climatic Divide and are nearly flat-lying along the Ohio River. One exception is in the northeastern area of the province (west of the Climatic Divide), where the rocks are gently folded and some carbonate rock crops out (Fenneman, 1938). The rocks in the Appalachian Plateaus Physiographic Province have been eroded to form steep hills and deeply incised valleys. Drainage patterns are dendritic.

The Valley and Ridge Physiographic Province in West Virginia consists of consolidated carbonate and siliciclastic sedimentary rocks that are folded sharply and extensively faulted (Fenneman, 1938). Northeast-trending valleys and ridges parallel the Climatic Divide. Drainage patterns are trellis.

The Blue Ridge Physiographic Province within West Virginia consists predominantly of metamorphosed sandstone and shale (Fenneman, 1938). The province has high relief between mountains and wide valleys that parallel the Climatic Divide. Drainage patterns are trellis.

The climate of West Virginia is primarily continental, with mild summers and cold winters. Major weather systems generally approach from the west and southwest, although polar continental air masses of cold, dry air that approach from the north and northwest are not unusual. Air masses from the Atlantic Ocean sometimes affect the area east of the Climatic Divide and less frequently affect the area west of the Climatic Divide. Generally, tropical continental masses of hot, dry air from the southwest affect the climate west of the Climatic Divide. Tropical maritime masses of warm, moist air from the Gulf of Mexico affect the climate east of the Climatic Divide more than west of the Climatic Divide. Evaporation from local and upwind land surfaces, lakes, and reservoirs also provides a source of moisture that affects the climate of the State (U.S. Geological Survey, 1991; National Oceanic and Atmospheric Administration, 2006a).

Annual precipitation averages about 42 to 45 in. statewide with about 60 percent received from March through August. July is the wettest month, and September through November are the driest months. Annual average precipitation in the State generally decreases northwestward from about 50 to $60 \mathrm{in}$. along the Climatic Divide to about $40 \mathrm{in}$. along the Ohio River; precipitation ranges from about 30 to 35 in. east of the Climatic Divide to about 40 in. in the extreme eastern tip of the State. Greater precipitation along and west of the Climatic Divide is a consequence of the higher elevations along the Divide and the orographic lifting of weather systems generally approaching from the west and southwest. Annual average snowfall follows the general pattern of annual average precipitation, decreasing northwestward from about 36 to 100 in. along the Climatic Divide to about 20 to 30 in. along the Ohio River. East of the Climatic Divide, annual average snowfall ranges from 24 to 36 in. (U.S. Geological Survey, 1991; Natural Resources Conservation Service, 2006; National Oceanic and Atmospheric Administration, 2006a, 2006b).

\section{Previous Studies}

Selected statistics for U.S. Geological Survey (USGS) streamflow-gaging stations representative of conditions during 1930-2002 were determined by Wiley (2006). In that study, a criterion-based sample of the record period was used to determine statistics representative of 1930-2002 rather than using the entire record period and (or) using record-extension techniques. The selected statistics included annual and seasonal hydrologically and biologically based low-flow frequency values, harmonic means, and flow-duration values (including variability index).

Wiley (2008) developed estimating procedures for the annual 1-, 3-, 7-, 14-, and 30-day 2-year; 1-, 3-, 7-, 14-, and 30-day 5-year; and 1-, 3-, 7-, 14-, and 30-day 10-year hydrologically based low-flow frequency values for unregulated streams in West Virginia. Equations and procedures for the annual 1-day 3-year and 4-day 3-year biologically based low-flow frequency values; the annual U.S. Environmental Protection Agency (USEPA) harmonic mean flows; and the annual 10-, 25-, 50-, 75-, and 90-percent flow-duration values 


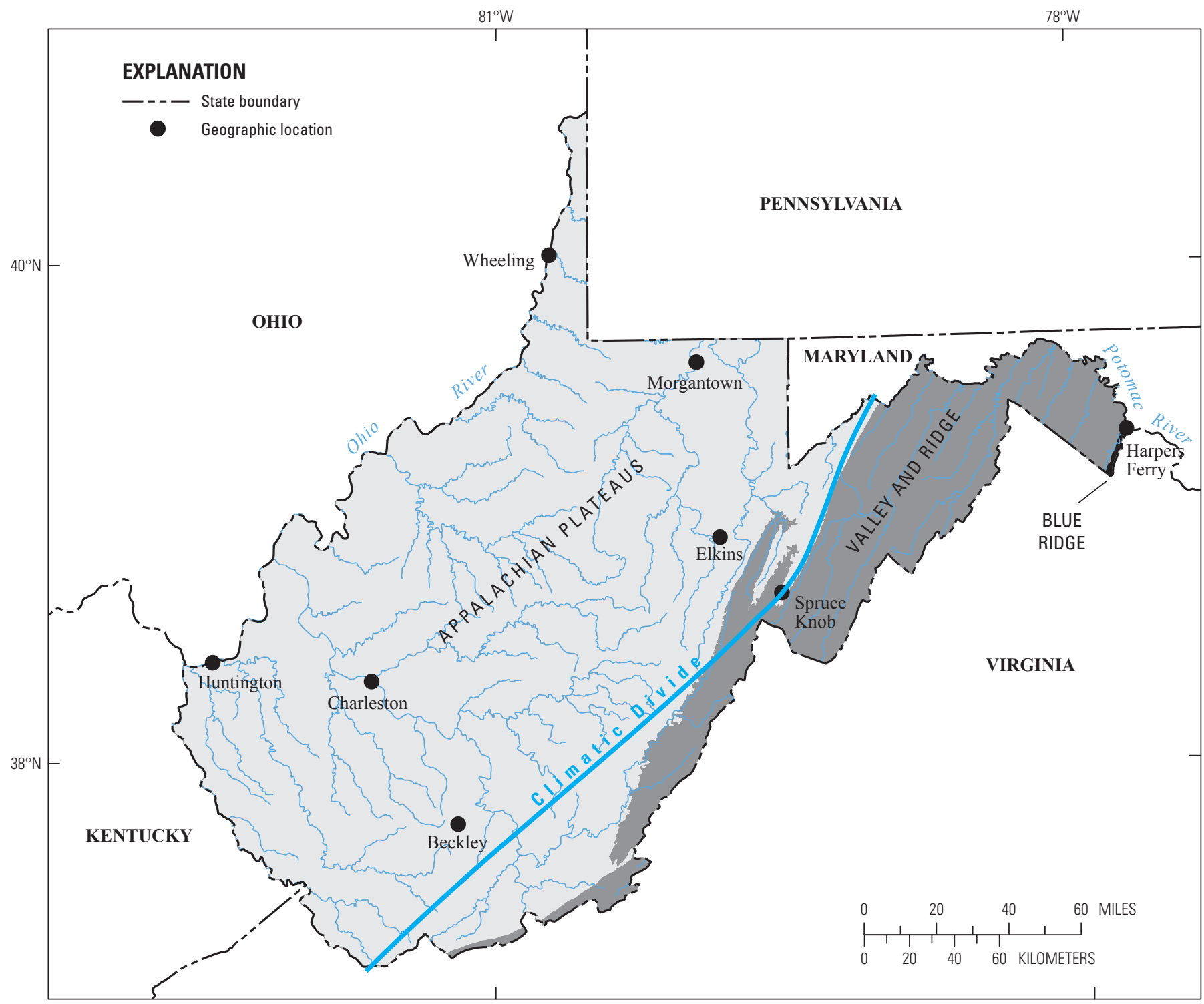

Base from U.S. Geological Survey 1:100,000 digital line graphics. Universal Transverse Mercator projection, zone 17, NAD 83.

Physiographic provinces from Fenneman, 1938

Figure 1. Appalachian Plateaus, Valley and Ridge, and Blue Ridge Physiographic Provinces, and Climatic Divide in West Virginia. (From Wiley and Atkins, 2010b, figure 2) 
also were developed. Regional equations were developed using ordinary least squares regression with flow statistics from USGS streamflow-gaging stations as dependent variables and basin characteristics for these streamflow-gaging stations as independent variables.

Methods for estimating seasonal flow statistics at ungaged locations were developed by Wiley and Atkins (2010a) using data from Wiley (2006). The seasons were defined as winter (January 1-March 31), spring (April 1June 30), summer (July 1-September 30), and fall (October 1-December 31). Regional equations for the seasonal 1-day 10-year, 7-day 10-year, and 30-day 5-year hydrologically based low-flow frequency values; the seasonal USEPA harmonic mean flows; and the seasonal 50-percent flow-duration values were developed using the same methods and regional boundaries used by Wiley (2006).

\section{Computation of Base Flows}

Base flow can be determined hydrographically using base-flow-recession methods (Olmsted and Hely, 1962; Riggs, 1964; Rorabaugh, 1964), curve-fitting methods (Pettyjohn and Henning, 1979; Linsley and others, 1982), and computer methods (Sloto and Crouse, 1996; Rutledge, 1998). A computer method is desired because computation time is substantially reduced, and a method that excludes individual biases of manipulation allows for reproducible results.

Daily mean discharge records for 14 USGS streamflowgaging stations in West Virginia that have no more than 4 years of missing record during 1930-2002 were used to compute base flows. A combination of two nearby stations was used to supplement the 14 stations and provide information near the southern border of the State, but no stations were available along the western border that met the record-length criterion. Fifteen stations (counting the combination of the two Tug Fork stations as one) are identical to those used by Wiley (2006) to study the variability of selected annual and seasonal flow statistics (fig. 2, table 1).

Base flows were computed for the 15 streamflow-gaging stations using the PART (streamflow PARTitioning) computer program developed by Rutledge (1998). Base flows for the 15 streamflow-gaging stations were computed annually, seasonally, and monthly for the period of record 1930 to 2002 and annually for five periods of record found by Wiley (2006) to have similar characteristics in annual minimum daily mean flows: 1930-42, 1943-62, 1963-69, 1970-79, and 1980-2002. The period 1930 to 2002 includes periods of droughts during the 1930s and 1960s and a wet period during the 1970s. Base flows were computed for climatic years (April 1 to March 31 of the indicated year) and for winter (January 1-March 31), spring (April 1-June 30), summer (July 1-September 30), and fall (October 1-December 31) for comparison with streamflow statistics computed by Wiley (2006).

The combined stations are Tug Fork near Kermit (station number, 03214000; drainage area, 1,188 $\mathrm{mi}^{2}$ ) and Tug Fork at
Kermit (03214500; 1,280 $\left.\mathrm{mi}^{2}\right)$. Most annual, and all seasonal and monthly, base-flow calculations were computed using records for Tug Fork near Kermit from 1936 to 1985 (climatic years). The record period 1936-85 was representative of the period 1930-2002 (Wiley, 2006, table 13, page 190). The annual base flows for the period 1980-2002 were computed for Tug Fork at Kermit (1986-2002) and were estimated for Tug Fork near Kermit by multiplying the base flows by the ratio of drainage areas $\left(1,188 \mathrm{mi}^{2} / 1,280 \mathrm{mi}^{2}\right)$.

\section{Comparison of Base Flows to Streamflow Statistics}

Mean annual base flow was computed for each of the 15 streamflow-gaging stations for the five characteristically similar record periods and for the period 1930-2002. The percent differences between mean annual base flow for the five record periods and the mean annual base flow for the period 1930-2002 were computed and compared to percent differences in streamflow statistics previously selected and computed by Wiley (2006, tables 2 and 3 ) to assess climate variability (table 2 ). The streamflow statistics previously selected by Wiley (2006) are the annual 1-day 10-year (1Q10), 7-day 10-year (7Q10), and 30-day 5-year (30Q5) hydrologically based low-flow frequency values; the 1-day 3-year (1B3) and 4-day 3-year (4B3) biologically based low-flow frequency values; and the annual USEPA harmonic mean flow. Differences between mean annual base flows computed for the five record periods and the values computed for 1930-2002 vary from -14.9 to 14.6 percent. Generally, differences between mean annual base flows computed for the five periods and the values computed for the period 1930-2002 vary less than percent differences between the selected streamflow statistics computed for the five sub-periods and the values computed for the period 1930-2002, particularly for the wet period 1970-79 when differences for mean annual base flow were 14.6 percent greater, and the differences between selected statistics were approximately 100 to 200 percent greater. The difference between mean annual base flow computed for the period 1963-69 and the value computed for the period 1930-2002, -14.9 percent, is slightly greater than that for the period 1930-42, -12.6 percent.

Mean seasonal base flows computed for 1930-2002 and previously selected seasonal streamflow statistics (Wiley, 2006, table 4) were compared to base flows for the five record periods to assess seasonal variability (table 3 ). Differences between base flows for the five record periods and mean seasonal base flows were less variable in the winter and spring, from -11.2 to 11.0 percent, than in summer and fall, from -47.0 to 43.6 percent. The difference for base flows for the summer of 1963-69, -47.0 percent, was less than the difference for fall of $1930-42,-24.2$ percent, and was the most negative seasonal percentage for all base flows, including those for all selected streamflow statistics for the five record periods. 


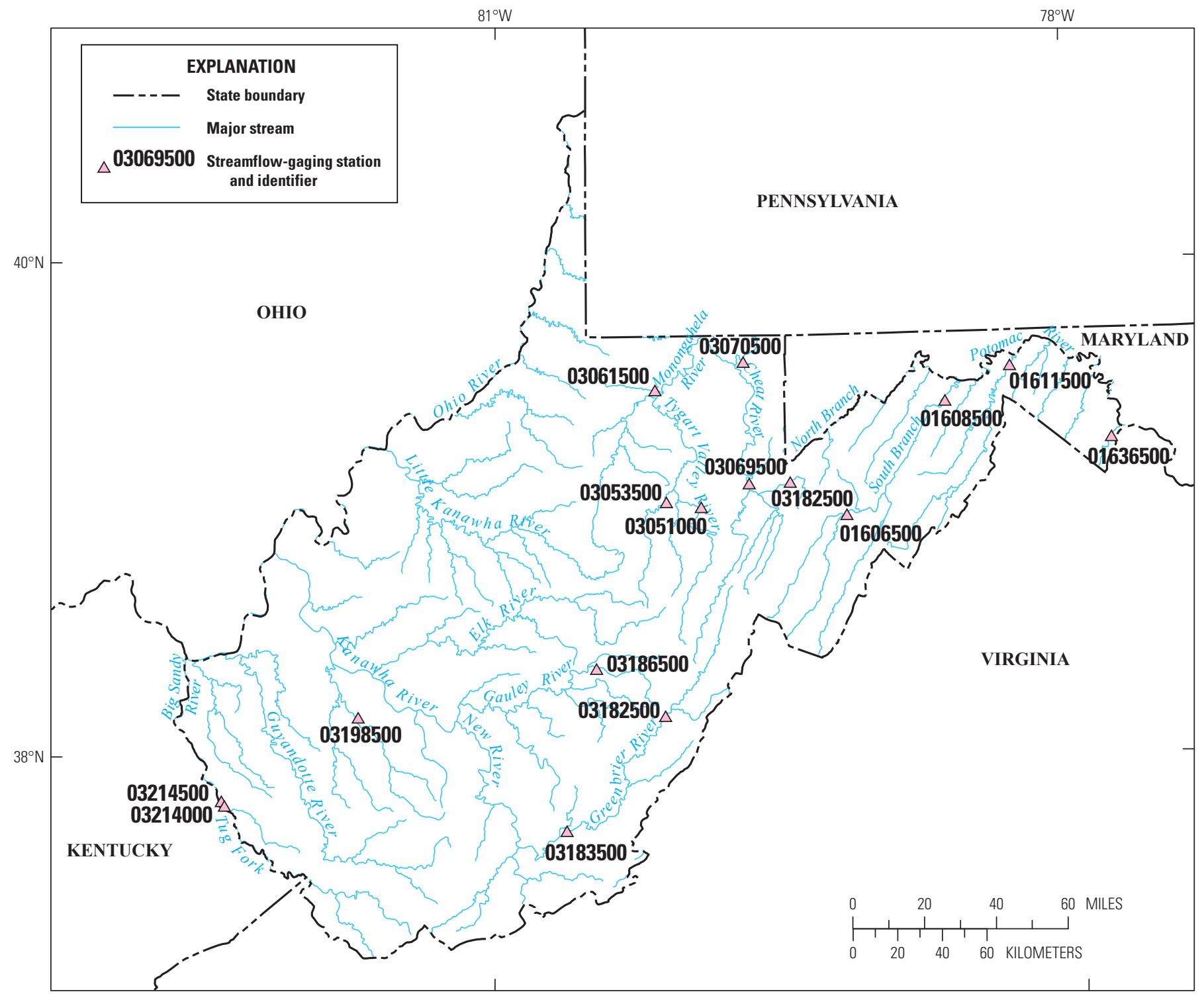

Base from U.S. Geological Survey 1:100,000 digital line graphics. Universal Transverse Mercator projection, zone 17, NAD 83.

Figure 2. Location of selected U.S. Geological Survey streamflow-gaging stations in West Virginia. 
Table 1. The streamflow-gaging stations used to compare base flows and selected streamflow statistics in West Virginia.

[Records for stations 03214000 and 03214500 were combined and counted as one station]

\begin{tabular}{|c|c|c|}
\hline $\begin{array}{l}\text { Station } \\
\text { number }\end{array}$ & Station name & $\begin{array}{l}\text { Drainage area, } \\
\text { in square miles }\end{array}$ \\
\hline 01606500 & South Branch Potomac River near Petersburg & 651 \\
\hline 01608500 & South Branch Potomac River near Springfield & 1,461 \\
\hline 01611500 & Cacapon River near Great Cacapon & 675 \\
\hline 01636500 & Shenandoah River at Millville & 3,041 \\
\hline 03051000 & Tygart Valley River at Belington & 406 \\
\hline 03053500 & Buckhannon River at Hall & 277 \\
\hline 03061500 & Buffalo Creek at Barrackville & 116 \\
\hline 03066000 & Blackwater River at Davis & 85.9 \\
\hline 03069500 & Cheat River near Parsons & 722 \\
\hline 03070500 & Big Sandy Creek at Rockville & 200 \\
\hline 03182500 & Greenbrier River at Buckeye & 540 \\
\hline 03183500 & Greenbrier River at Alderson & 1,364 \\
\hline 03186500 & Williams River at Dyer & 128 \\
\hline 03198500 & Big Coal River at Ashford & 391 \\
\hline 03214000 & Tug Fork near Kermit & 1,188 \\
\hline 03214500 & Tug Fork at Kermit & 1,280 \\
\hline
\end{tabular}

Table 2. Average, minimum, and maximum differences between mean annual base flows and selected annual statistics computed for 1930-2002, and those computed for the indicated record periods for 15 streamflow-gaging stations in West Virginia.

[Modified from Wiley, 2006, tables 2 and 3. Top number in each group is the average difference. Minimum difference followed by maximum difference in parentheses. Station numbers are 01606500, 01608500, 01611500, 01636500, 03051000, 03053500, 03061500, 03066000, 03069500, 03070500, 03182500, 03183500, 03186500, 03198500, and combined stations 03214000 and 03214500. A negative value means the average for the indicated record period is less than the average for 1930-2002; a positive value means the average for the indicated record period is greater than the average for 1930-2002. USEPA, U.S. Environmental Protection Agency]

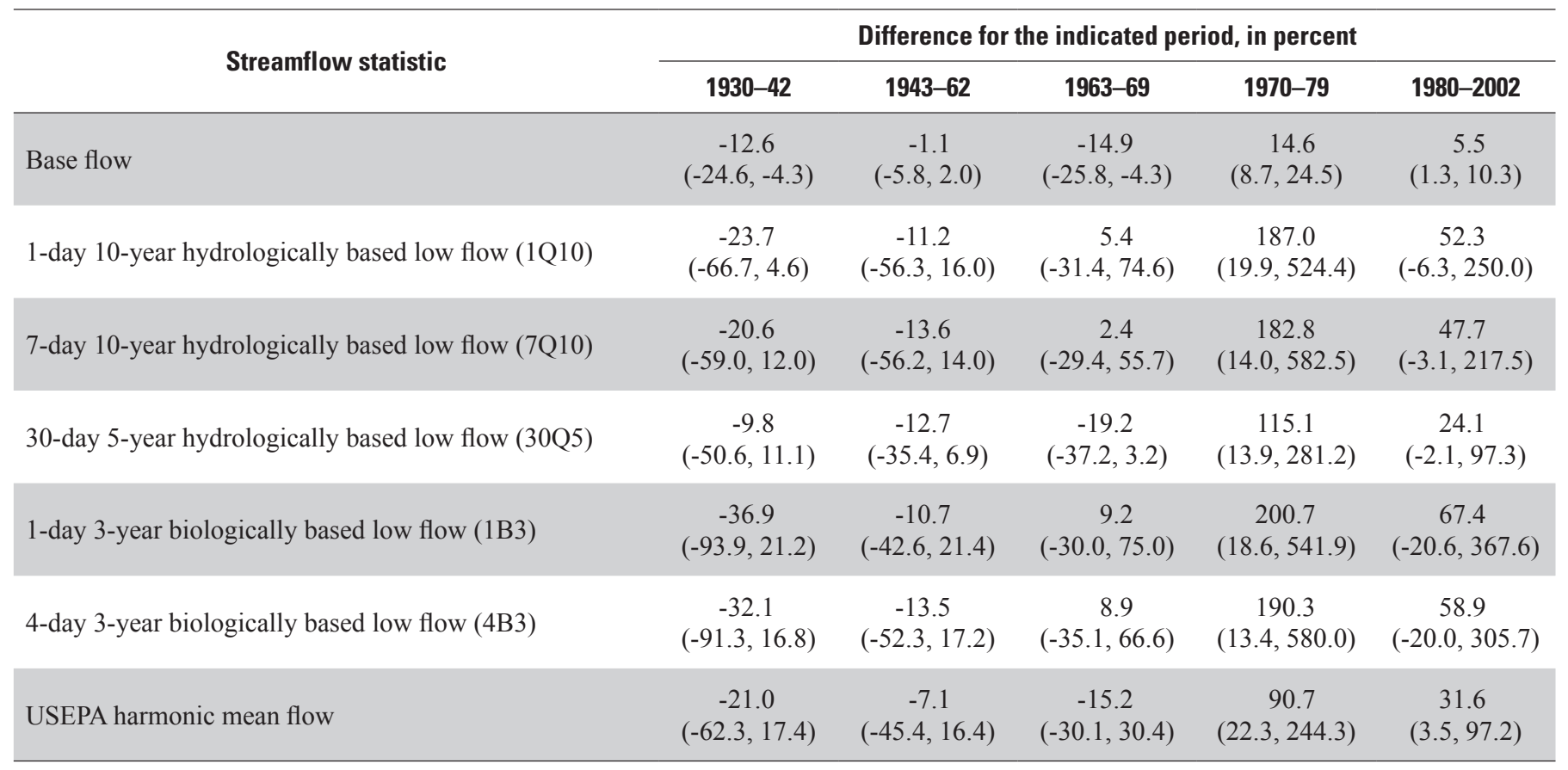


Table 3. Average differences between base flows and selected seasonal statistics computed for 1930-2002, and those computed for the indicated record periods for 15 streamflow-gaging stations in West Virginia. (Modified from Wiley, 2006, table 4)

[Modified from Wiley, 2006, table 4. Winter, January 1-March 31; spring, April 1-June 30; summer, July 1-September 30; fall, October 1-December 31; station numbers are 01606500, 01608500, 01611500, 01636500, 03051000, 03053500, 03061500, 03066000, 03069500, 03070500, 03182500, 03183500, 03186500, 03198500, and combined stations 03214000 and 03214500 . A negative value means the average for the indicated record period is less than the average for 1930-2002; a positive value means the average for the indicated record period is greater than the average for 1930-2002]

\begin{tabular}{|c|c|c|c|c|c|}
\hline \multirow{2}{*}{ Season } & \multicolumn{5}{|c|}{ Difference for the indicated period, in percent } \\
\hline & 1930-42 & $1943-62$ & $1963-69$ & 1970-79 & 1980-2002 \\
\hline \multicolumn{6}{|c|}{ Base flow } \\
\hline Winter & -11.0 & 3.5 & -11.2 & 11.0 & 1.2 \\
\hline Spring & -10.1 & -0.9 & -10.2 & 1.9 & 8.2 \\
\hline Summer & -8.9 & -2.7 & -47.0 & 21.0 & 12.5 \\
\hline Fall & -24.2 & -11.7 & -16.3 & 43.6 & 7.6 \\
\hline \multicolumn{6}{|c|}{ 1-day 10 -year hydrologically based low flow (1010) } \\
\hline Winter & -9.7 & 6.0 & -11.5 & 69.4 & -2.6 \\
\hline Spring & -12.5 & 35.7 & -29.5 & 32.4 & 9.2 \\
\hline Summer & -24.8 & -6.5 & -3.6 & 175.4 & 44.8 \\
\hline Fall & -26.2 & -18.8 & 6.3 & 167.2 & 62.2 \\
\hline \multicolumn{6}{|c|}{ 7-day 10-year hydrologically based low flow (7010) } \\
\hline Winter & -12.2 & -4.4 & -17.3 & 58.5 & 0.1 \\
\hline Spring & -17.6 & 19.5 & -29.2 & 27.1 & 3.4 \\
\hline Summer & -21.8 & -8.3 & -6.0 & 176.2 & 39.2 \\
\hline Fall & -25.6 & -20.4 & 10.6 & 140.4 & 55.3 \\
\hline \multicolumn{6}{|c|}{ 30-day 5-year hydrologically based low flow (3005) } \\
\hline Winter & -19.2 & 2.3 & -31.4 & 31.7 & 6.5 \\
\hline Spring & -18.7 & 13.1 & -34.3 & 5.1 & 6.8 \\
\hline Summer & -12.5 & -6.3 & -29.2 & 85.4 & 20.0 \\
\hline Fall & -25.6 & -17.5 & -16.5 & 104.6 & 22.9 \\
\hline \multicolumn{6}{|c|}{ 1-day 3-year biologically based low flow (1B3) } \\
\hline Winter & -11.4 & -4.2 & 1.7 & 73.8 & 5.8 \\
\hline Spring & -30.2 & 15.7 & 4.3 & 4.7 & 57.9 \\
\hline Summer & -35.0 & -5.4 & 0.8 & 170.2 & 50.8 \\
\hline Fall & -35.7 & -15.1 & 7.8 & 207.7 & 72.2 \\
\hline \multicolumn{6}{|c|}{ 4-day 3-year biologically based low flow (4B3) } \\
\hline Winter & -8.1 & -4.4 & -13.2 & 59.1 & 5.1 \\
\hline Spring & -24.3 & 18.6 & 3.0 & 0.6 & 53.7 \\
\hline Summer & -33.2 & -5.8 & -2.8 & 159.3 & 39.1 \\
\hline Fall & -40.0 & -20.3 & 7.3 & 170.2 & 54.1 \\
\hline \multicolumn{6}{|c|}{ U.S. Environmental Protection Agency harmonic-mean flow } \\
\hline Winter & -5.7 & 5.5 & -19.5 & 37.9 & -1.9 \\
\hline Spring & -25.3 & 4.0 & -14.9 & 3.8 & 28.6 \\
\hline Summer & -21.9 & 1.0 & -27.9 & 86.3 & 31.8 \\
\hline Fall & -18.3 & -14.3 & 2.9 & 142.5 & 41.0 \\
\hline
\end{tabular}


Mean seasonal and mean monthly base flows as percentages of mean annual base flows for 1930-2002 were compared (fig. 3). Summer base flows and the monthly base flows for July, August, and September are approximately equal, within 7.4 percentage points. Mean seasonal base flows for spring, fall, and winter show poor agreement with the mean monthly values, ranging from -35.4 percentage points between fall and the month of October to 58.3 percentage points between spring and the month of April. Base flows for the month of October are more similar to those of the summer season and summer months (within 7.4 percentage points) than to base flows for fall (35.4 percentage points less than fall base flows). Base flows for March were the highest at 84.0 percent of the mean annual base flow, and base flows for September were the lowest at -74.0 percent of the mean annual base flow.

Mean annual base flows (fig. 4) and mean seasonal base flows (fig. 5) were compared to various annual and seasonal duration flows (Searcy, 1959; Wiley, 2006) to determine whether annual and seasonal duration flows can be used as surrogate statistics for estimating base flows. (A duration flow is a flow that is equaled or exceeded some percentage of the time; for example, the 50-percent duration flow is equaled or exceeded 50 percent of the time.) All possible comparisons between annual and seasonal base flows and various annual and seasonal duration flows were evaluated to determine the minimum standard error. The mean annual base flow was approximated by the annual 50-percent duration flow with a standard error of 10.3 percent (fig. 4). The mean spring base flow was approximated by the spring 50- and 55-percent duration flows with a 6.8 percent standard error and the annual 45-percent duration flow with a 14.6 percent standard error (fig. 5). Summer 45- to 50-percent duration flow with a 6.7 percent standard error and annual 75-percent duration flow with a 11.8 percent standard error can be used as surrogates to estimate summer base flow. Fall 45-percent duration flow with 15.2 percent error and annual 55-percent duration flow with 11.2 percent error can be used to estimate fall base flow. Winter 60-percent duration flow with 8.5 percent error and annual 35 -percent duration flow with 11.1 percent error can be used to estimate winter base flow (fig. 5).

\section{Examples of Estimating Base Flows}

Base flows at streamflow-gaging stations and ungaged locations can be estimated using the surrogate statistics, which can be determined using procedures described by Wiley (2008). Mean annual base flows at ungaged locations can be interpolated from duration flows determined from previously generated equations when equations for the desired duration flows are not available. Mean seasonal base flows can be determined only from flows at the streamflow-gaging stations because only equations for the seasonal 50-percent duration flows are available from Wiley and Atkins (2010a). Base-flow estimates determined using more than one surrogate statistic

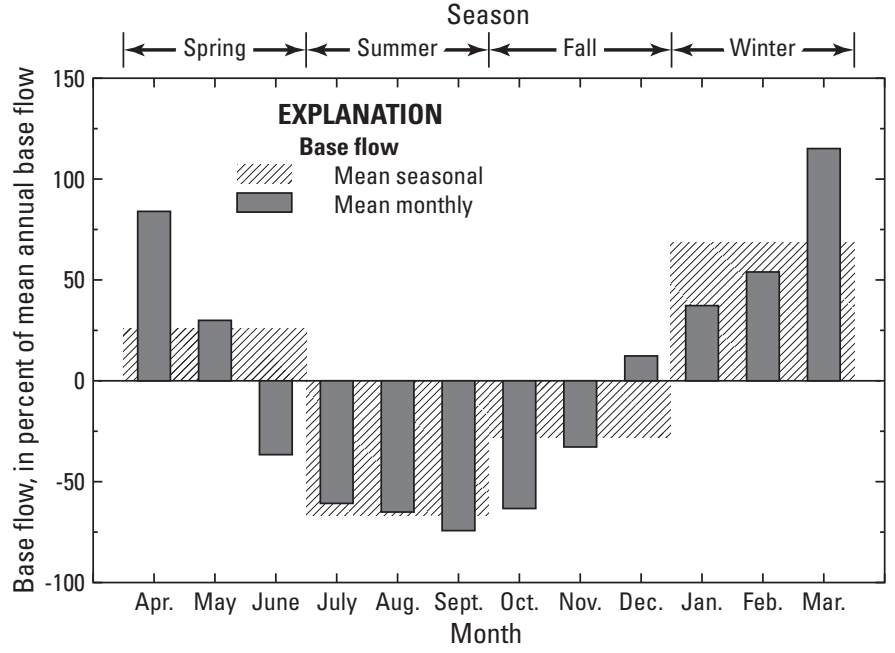

Figure 3. Mean seasonal and mean monthly base flows as percentage of mean annual base flows for 15 streamflow-gaging stations in West Virginia, 1930-2002.

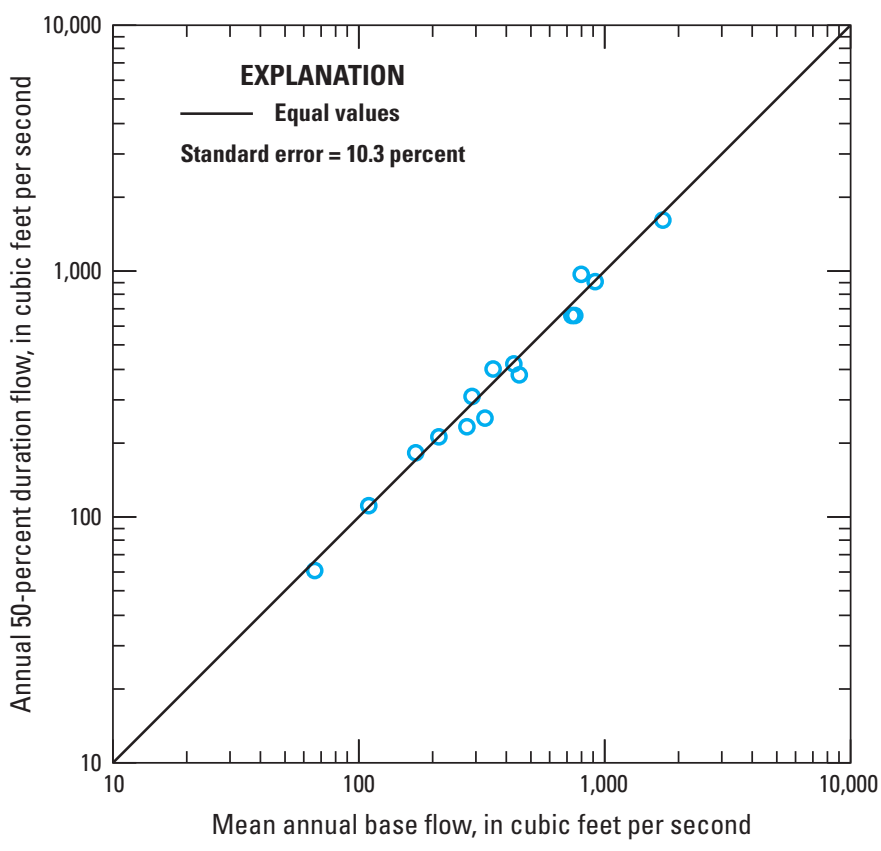

Figure 4. Mean annual base flows in relation to annual 50-percent duration flows for 15 streamflow-gaging stations in West Virginia, 1930-2002. 

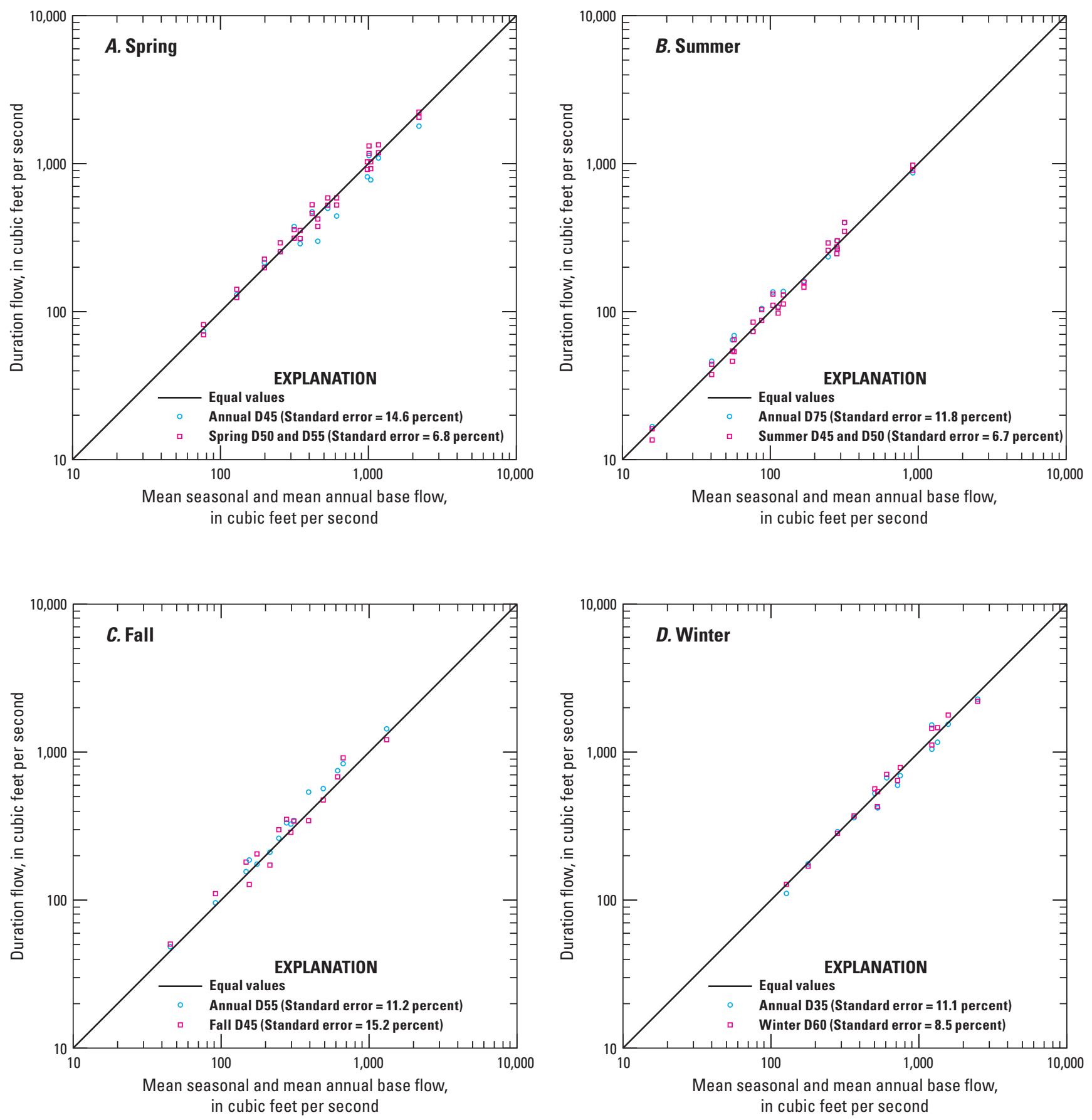

Figure 5. Mean seasonal and mean annual base flows in relation to selected duration flows for 15 streamflow-gaging stations during $A$, spring, $B$, summer, $C$, fall, and $D$, winter in West Virginia, 1930-2002. (Dn, n-percent duration flow) 
can be averaged. Errors for estimated base flows are a summation of the standard error of the surrogate relation and the error of any regression equation used.

- Example 1-The mean annual base flow at the streamflow-gaging station Skin Creek at Brownsville (03057500) can be estimated by determining the annual 50-percent duration flow following procedures described by Wiley $(2008$, p. 12) in the section "At a Gaging Station." The procedure for "At a Gaging Station" is to read the value for the statistics from table 11 presented by Wiley (2006). The mean annual base flow is estimated from the surrogate statistic which is the 50-percent duration flow (fig. 4). The mean annual base flow is $13.4 \mathrm{ft}^{3} / \mathrm{s}$ (the 50 -percent duration flow presented by Wiley, 2006, p.89).

- Example 2-The mean summer base flow at the streamflow-gaging station Skin Creek at Brownsville (03057500) can be estimated by averaging the surrogate statistics (fig. 5). The mean summer base flow is an average of (1) the annual 75-percent duration flow and (2) the average of the summer 45- and 50-percent duration flows. The annual and seasonal duration flows are determined using procedures described by Wiley (2008, p. 12) in "At a Gaging Station," which is to read values from table 11 presented by Wiley (2006). The mean summer base flow is $2.8 \mathrm{ft}^{3} / \mathrm{s}\left(3.2 \mathrm{ft}^{3} / \mathrm{s}+\left(2.8 \mathrm{ft}^{3} / \mathrm{s}\right.\right.$ $\left.+2.2 \mathrm{ft}^{3} / \mathrm{s} / 2\right) / 2$ ) based on values for surrogate statistics from Wiley (2006, p. 89).

- Example 3-The mean fall base flow at an ungaged location with a drainage area (AU) of $84.2 \mathrm{mi}^{2}$ upstream from the streamflow-gaging station South Fork South Branch Potomac River at Brandywine (01607500) can be estimated using equation 4 from Wiley (2008):

$$
Q_{U}=Q_{K}\left(R_{U / K}\right)^{E X}
$$

where

$$
\begin{aligned}
& Q_{U} \quad \text { is the value of the unknown streamflow } \\
& \text { statistic, in } \mathrm{ft}^{3} / \mathrm{s} \text {; } \\
& Q_{K} \quad \text { is the value of the known streamflow statistic, } \\
& \text { in } \mathrm{ft}^{3} / \mathrm{s} \text {; } \\
& R_{U / K} \quad \text { is the ratio of the drainage area at the location } \\
& \text { of the unknown streamflow }\left(A_{U}\right) \text { to the } \\
& \text { drainage area at the location of the known } \\
& \text { streamflow }\left(A_{K}\right) \text {, unitless; and } \\
& E X \quad \text { is the exponent for the particular statistic } \\
& \text { (Wiley, 2008, table 3), unitless. }
\end{aligned}
$$

This equation can be used because there are no additional streamflow-gaging stations upstream on the same stream and the size of the drainage area is within the limits for which the estimate can be made using drainage-area ratios. The surrogate statistic (fig. 5), annual 55-percent duration flow, for the streamflowgaging station is $33.7 \mathrm{ft}^{3} / \mathrm{s}\left(Q_{K}\right)$ (Wiley, 2006, p. 73), and the drainage area at the streamflow-gaging stations is $103 \mathrm{mi}^{2}\left(A_{K}\right)$ (Paybins, 2008). The ratio of drainage areas $\left(R_{U / K}\right)$ is $A_{U}$ divided by $A_{K}$, or $84.2 \mathrm{mi}^{2}$ divided by $103 \mathrm{mi}^{2}$, which is 0.817 . The exponent $(E X)$ for the annual 55-percent duration flow is interpolated from the value for D50, 0.96 (Wiley, 2008, table 3), and the value for D75, 1.01 (Wiley, 2008, table 3), as 0.97 $(0.96+(55-50)(1.01-0.96) /(75-50))$. Substituting into equation 4 from Wiley (2008), the mean fall base flow (annual 55-percent duration flow) at the ungaged location $\left(Q_{U}\right)$ is $27.7 \mathrm{ft}^{3} / \mathrm{s}$. The value of $R_{U / K}$ of 0.817 is greater than the upstream limit $\left(R_{U S}\right)$ of 0.21 (Wiley, 2008, table 3), indicating the establishment of a partial-record station (Wiley, 2008, p. 12) at the ungaged location is not required to estimate the flow statistic at this location.

- Example 4-The mean winter base flow at an ungaged location with a drainage area of $1,450 \mathrm{mi}^{2}$ $\left(A_{U}\right)$ located downstream from the streamflow-gaging station Greenbrier River at Alderson (03183500), and upstream from the streamflow-gaging station Greenbrier River at Hilldale (03184000) can be estimated using equation 6 from Wiley (2008):

$$
Q_{U}=\left[Q_{U S}\left(A_{D S}-A_{U}\right)+Q_{D S}\left(A_{U}-A_{U S}\right)\right] /\left(A_{D S}-A_{U S}\right),
$$

when

$$
R_{U / K}<R_{D S} \quad \begin{gathered}
\text { at upstream location and } R_{U / K}>R_{U S} \text { at } \\
\text { downstream location, }
\end{gathered}
$$

or when

$$
\begin{gathered}
R_{U / K} \geq R_{D S} \quad \begin{array}{c}
\text { at upstream location and } R_{U / K} \leq R_{U S} \text { at } \\
\text { downstream location; and }
\end{array} \\
Q_{K E} \quad \begin{array}{c}
\text { at the upstream location }>Q_{U S} \text { and } Q_{K E} \text { at the } \\
\text { downstream location }>Q_{D S} \text { or }
\end{array} \\
Q_{K E} \quad \begin{array}{c}
\text { at the upstream location }<Q_{U S} \text { and } Q_{K E} \\
\text { downstream location }<Q_{D S}
\end{array} \text { and the }
\end{gathered}
$$

where

$Q_{U} \quad$ is the value of the unknown streamflow statistic, in $\mathrm{ft}^{3} / \mathrm{s}$;

$Q_{U S} \quad$ is the value of the streamflow statistic at the upstream location, in $\mathrm{ft}^{3} / \mathrm{s}$;

$Q_{D S} \quad$ is the value of the streamflow statistic at the downstream location, in $\mathrm{ft}^{3} / \mathrm{s}$;

$Q_{K E} \quad$ is the regional equation evaluated at the location of the value of the known streamflow statistic, in $\mathrm{ft}^{3} / \mathrm{s}$;

$A_{U} \quad$ is the drainage area at the location of the unknown value of the streamflow statistic, in $\mathrm{mi}^{2}$;

$A_{U S} \quad$ is the drainage area at the upstream location, in $\mathrm{mi}^{2}$;

$A_{D S} \quad$ is the drainage area at the downstream location, in $\mathrm{mi}^{2}$; 
$R_{U S} \quad$ is the upstream limit of the ratio of drainage areas (Wiley, 2008, table 3), unitless; and

$D_{S} \quad$ is the downstream limit of the ratio of drainage areas (Wiley, 2008, table 3), unitless.

The drainage area is $1,364 \mathrm{mi}^{2}\left(A_{U S}\right)$ for Greenbrier River at Alderson and $1,619 \mathrm{mi}^{2}\left(A_{D S}\right)$ for Greenbrier River at Hilldale (Paybins, 2008). This equation can be used because the ratio of drainage areas $\left(R_{U / K}\right.$, or $A_{U}$ divided by $A_{K}$ ) is equal to $1,450 \mathrm{mi}^{2}$ divided by $1,364 \mathrm{mi}^{2}$, or 1.06 , which is less than the $R_{D S}$ of 2 (Wiley, 2008, table 3) at the upstream location, and the $R_{U / K}\left(A_{U}\right.$ divided by $A_{K}$, or $1,450 \mathrm{mi}^{2}$ divided by $1,619 \mathrm{mi}^{2}$ ) of 0.896 is greater than the $R_{U S}$ of 0.21 (Wiley, 2008, table 3) at the downstream location. The surrogate statistics (fig. 5), the annual 35-percent duration flow, at Alderson $\left(Q_{U S}\right)$ is $1,540 \mathrm{ft}^{3} / \mathrm{s}$ (Wiley, 2006, p. 116) and at Hilldale $\left(Q_{D S}\right)$ is $1,840 \mathrm{ft}^{3} / \mathrm{s}$ (Wiley, 2006, p. 117). By substituting these values into equation 6 , the mean winter base flow at the ungaged location $\left(Q_{U}\right)$ is $1,641 \mathrm{ft}^{3} / \mathrm{s}$.

- Example 5-The mean spring base flow for Lunice Creek just downstream from the confluence of North and South Forks of Lunice Creek in Grant County (Rig 71/2-minute USGS topographic map) can be calculated from regional equations. (There are no streamflowgaging stations on Lunice Creek or North Fork Lunice Creek.) The surrogate statistic (fig. 5), annual 45-percent duration flow, will be interpolated from available equations for the annual 25- and 50-percent duration flows. The streams are in the Eastern Panhandle Region (Wiley, 2008, fig. 3), and the drainage area is $52.78 \mathrm{mi}^{2}$ (Wiley and others, 2007, p. 26). The drainage area is within the limits of the regional equation from 8.83 to $3.41 \mathrm{mi}^{2}$ (Wiley, 2008, table 1), indicating that the procedure is valid. Installation of a partialrecord station would not improve the estimate because the technique of transferring statistics from a streamflow-gaging station is limited to streamflows at and less than the 50-percent duration flow (Wiley, 2008, p.12). The annual 25- and 50-percent duration flows were calculated from the regression equations for the Eastern Panhandle Region (Wiley, 2008, table 1):

$$
D 25=1.70 D A^{0.937}
$$

and

$$
D 50=6.21 \times 10^{-1} D A^{0.969},
$$

where

$$
D A \quad \text { is the drainage area, in } \mathrm{mi}^{2} \text {. }
$$

The annual 25- and 50-percent duration flows are calculated as $69.9 \mathrm{ft}^{3} / \mathrm{s}$ and $29.0 \mathrm{ft}^{3} / \mathrm{s}$, respectively. The mean spring base flow is interpolated for the surrogate statistic, the annual 45-percent duration flow, as $37.2 \mathrm{ft}^{3} / \mathrm{s}(69.9-(45-25)(69.9-29.0) /(50-25))$.

\section{Limitations of Base-Flow Estimates}

Base-flow estimates are applicable only to unregulated streams in West Virginia because data used to develop methods were collected only from unregulated streams. All estimates are representative of the period 1930-2002. Estimates are best not made for streams regulated by large lakes, ponds, or navigation dams.

A partial-record station (Wiley, 2008, p. 12) can be established where there is some measurable streamflow, but estimates for ungaged locations are best not made without first determining that the streams involved are not losing or gaining water to or from underground mines or karst geology. A partial-record station will not help in determining the annual surrogate statistic for spring and winter base flows, the 45- and 35 -percent duration flows, because the technique of transferring statistics from streamflow-gaging stations is limited to streamflows at and less than the 50-percent duration flow (Wiley, 2008, p.12).

Estimates for ungaged locations are best made only for perennial streams because data used to develop methods were collected only from perennial streams. The median drainage area upstream from the location where an intermittent stream becomes perennial was determined by Paybins (2003) to be 40.8 acres $\left(0.064 \mathrm{mi}^{2}\right)$. This value ranged from 10.2 to 150.1 acres ( 0.016 to $\left.0.235 \mathrm{mi}^{2}\right)$ in a limited study of 36 sites conducted in the southern coal fields of West Virginia and differed by region, with a median of 66.1 acres $\left(0.103 \mathrm{mi}^{2}\right)$ in the northeastern part of the southern coal fields and 34.8 acres $\left(0.054 \mathrm{mi}^{2}\right)$ in the southwestern part (Paybins, 2003). The procedures are not intended for use with drainage areas less than $0.05 \mathrm{mi}^{2}$ because the streams are likely not perennial; base flows for drainage areas less than $0.25 \mathrm{mi}^{2}$ can be estimated with some certainty only when there is some determination (such as a field observation at low streamflow) that the stream is perennial.

Estimates are not conservative at the confluence of streams. The value for base flow downstream from the confluence of two streams will not equal the summation of the values estimated upstream from the confluence.

Caution is called for when making estimates for areas with underground mining and karst terrain. Base flows may be reduced in streams that are "dewatered" by underlying underground mines or can be increased in streams that are downdip (where the elevation is lower and where the rock strata slope toward the stream) from flooded underground mines. Water also can be transferred between basins by drainage through coal mines and in karst terrain. Base flows at outflow points of large basins that are stratigraphically below mined coal beds likely would be increased from the pre-mining condition, except where large interbasin transfer of water occurs. 


\section{Summary and Conclusions}

The U.S. Geological Survey, in cooperation with the West Virginia Department of Environmental Protection, Division of Water and Waste Management, compared base flows with published statistics at 15 streamflow-gaging stations to assess climate variability and determine surrogate statistics for estimating annual and seasonal base flows on unregulated streams in West Virginia. The seasons were defined as winter (January 1-March 31), spring (April 1-June 30), summer (July 1September 30), and fall (October 1-December 31).

Mean annual and seasonal base flows representing the period 1930-2002 were compared to base flows and selected statistics computed for five sub-periods with similar characteristics in annual-minimum daily mean flows (1930-42, 1943-62, 1963-69, 1970-79, and 1980-2002) to assess climate variability. The differences in mean annual base flows range from -14.9 to 14.6 percent for the five sub-periods compared to the values for the period 1930-2002. The differences between mean seasonal base flows and base flows for the period 1930-2002 are less variable in the winter and spring, -11.2 to 11.0 percent, and more variable in the summer and fall, -47.0 to 43.6 percent.

Mean summer base flow (July-September) and mean monthly base flows for July, August, September, and October are approximately equal, within 7.4 percentage points of mean-annual base flow. The mean annual base flow is approximately equal, with a standard error of 10.3 percent, to the annual 50-percent duration flow. The mean spring base flow is approximately equal to the annual 45 -percent duration flow with a standard error of 14.6 percent and the spring 50 - to 55 -percent duration flow with a standard error of 6.8 percent. The mean summer base flow is approximately equal to the annual 75-percent duration flow with a standard error of 11.8 percent and the summer 45 - to 50 -percent duration flow with a standard error of 6.7 percent. The mean fall base flow is approximately equal to the annual 55-percent duration flow with a standard error of 11.2 percent and the fall 45 -percent duration flow with a standard error of 15.2 percent. The mean winter base flow is approximately equal to the annual 35 -percent duration flow with a standard error of 11.1 percent and the winter 60-percent duration flow with a standard error of 8.5 percent.

Annual and seasonal base flows representative of the period 1930-2002 at unregulated streamflow-gaging stations and ungaged locations in West Virginia can be estimated using previously published values of surrogate statistics and procedures. Procedures that establish a partial-record station will not help to determine the spring and winter base flows because the technique of transferring statistics from a streamflow-gaging station is limited to streamflows at and less than the 50-percent duration flow. Estimates are best not made for streams regulated by large lakes, ponds, or navigation dams. Caution is called for when making estimates in areas of underground mining and karst terrain.

\section{References Cited}

Fenneman, N.M., 1938, Physiography of Eastern United States: New York, McGraw-Hill, 714 p.

Linsley, R.K., Jr., Kohler, M.A., and Paulhus, J.L.H., 1982, Hydrology for engineers ( $3 \mathrm{~d}$ ed.): New York, McGraw-Hill, $508 \mathrm{p}$.

National Oceanic and Atmospheric Administration, 2006a, Climate of West Virginia, accessed September 30, 2006, at http://cdo.ncdc.noaa.gov/climatenormals/clim60/states/ Clim_WV_01.pdf.

National Oceanic and Atmospheric Administration, 2006b, Total precipitation in inches by month for climate divisions, accessed September 30, 2006, at http://www.cdc.noaa.gov/ USclimate/pcp.state.19712000.climo.html.

Natural Resources Conservation Service, 2006, West Virginia precipitation data/maps, accessed September 30, 2006, at http://www.ncgc.nrcs.usda.gov/products/datasets/climate/ data/precipitation-state/wv.html.

Olmsted, F.H., and Hely, A.G., 1962, Relation between ground water and surface water in Brandywine Creek basin Pennsylvania: U.S. Geological Survey Professional Paper 417-A, $21 \mathrm{p}$.

Paybins, K.S., 2003, Flow origin, drainage area, and hydrologic characteristics for headwater streams in the mountaintop coal-mining region of southern West Virginia, 2000-01: U.S. Geological Survey Water-Resources Investigations Report 02-4300, $20 \mathrm{p}$.

Paybins, K.S., 2008, Basin characteristics for selected gaging stations in and near West Virginia: U.S. Geological Survey Scientific Investigations Report 2008-1087, 9 p.

Pettyjohn, W.A., and Henning, Roger, 1979, Preliminary estimate of ground-water recharge rates, related streamflow and water quality in Ohio: Columbus, Ohio, Ohio State University Water Resources Center, Project Completion Report $552,323 \mathrm{p}$.

Riggs, H.C., 1964, The base-flow recession curve as an indicator of ground water: International Association of Scientific Hydrology, Publication 63, p. 352-363.

Rorabaugh, M.I., 1964, Estimating changes in bank storage and groundwater contribution to streamflow: International Association of Scientific Hydrology, Publication 63, p. 432-441.

Rutledge, A.T., 1998, Computer programs for describing the recession of groundwater discharge and for estimating mean ground-water recharge and discharge from streamflow records - update: U.S. Geological Survey Water-Resources Investigations Report 98-4148, p. 43. 
Searcy, J.K., 1959, Flow-duration curves-Manual of hydrology - part 2, Low-flow techniques: U.S. Geological Survey Water-Supply Paper 1542-A, 33 p.

Sloto, R.A. and Crouse, M.Y., 1996, HYSEP: A computer program for streamflow hydrograph separation and analysis: U.S. Geological Survey Water-Resources Investigations Report 96-4040, 46 p.

U.S. Geological Survey, 1990, National water summary 1987-Hydrologic events and water supply and use: U.S. Geological Survey Water-Supply Paper 2350, 553 p.

U.S. Geological Survey, 1991, National water summary 1988-89-Hydrologic events and floods and droughts: U.S. Geological Survey Water-Supply Paper 2375, 591 p.

U.S. Geological Survey, 2006, The National Map, accessed September 30, 2006, at http://nationalmap.gov.

Wiley, J.B., 2006, Low flow analysis and selected flow statistics representative of the period 1930-2002 for streamflowgaging stations in or near West Virginia: U.S. Geological Survey Scientific Investigations Report 2006-5002, 190 p.

Wiley, J.B., 2008, Estimating selected streamflow statistics representative of 1930-2002 in West Virginia: U.S. Geological Survey Scientific Investigations Report 2008-5105, $24 \mathrm{p}$.

Wiley, J.B., and Atkins, J.T., Jr., 2010a, Estimation of selected seasonal streamflow statistics representative of 1930-2002 in West Virginia: U.S. Geological Survey Scientific Investigations Report 2010-5185, 20 p.

Wiley, J.B., and Atkins, J.T., Jr., 2010b, Estimation of floodfrequency discharges for rural, unregulated streams in West Virginia: U.S. Geological Survey Scientific Investigations Report 2010-5033, 78 p.

Wiley, J.B., Atkins, J.T., Jr., and Tasker, G.D., 2000, Estimating magnitude and frequency of peak discharges for rural, unregulated, streams in West Virginia: U.S. Geological Survey Water-Resources Investigations Report 00-4080, 93 p.

Wiley, J.B., Hunt, M.L., and Stewart, D.K., 2007, Drainage areas of the Potomac River Basin, West Virginia ( $3 \mathrm{~d}$ ed.): U.S. Geological Survey Open File Report 95-292, 63 p. 



\section{Appendix 1}

Annual and seasonal base flows at 15 streamflow-gaging stations in West Virginia for the period 1930-2002. Two stations are combined and counted as one. Period 1930-2002 consists of five sub-periods-1930-42, 1943-62, 1963-69, 1970-79, and 1980-2002. 
Appendix 1. Annual and seasonal base flows at 15 streamflow-gaging stations in West Virginia, 1930-2002.

[Winter, January 1-March 31; spring, April 1-June 30; summer, July 1-September 30; fall, October 1-December 31]

\begin{tabular}{|c|c|c|c|c|c|c|}
\hline \multirow{2}{*}{ Season } & \multicolumn{6}{|c|}{ Base flow for the indicated period, in cubic feet per second } \\
\hline & 1930-2002 & 1930-42 & 1943-62 & $1963-69$ & 1970-79 & 1980-2002 \\
\hline \multicolumn{7}{|c|}{01606500 South Branch Potomac River near Petersburg } \\
\hline Annual & 452 & 411 & 451 & 361 & 510 & 480 \\
\hline Winter & 724 & 647 & 735 & 610 & 815 & 753 \\
\hline Spring & 619 & 587 & 636 & 518 & 600 & 661 \\
\hline Summer & 170 & 173 & 170 & 92 & 182 & 185 \\
\hline Fall & 297 & 235 & 262 & 224 & 442 & 321 \\
\hline \multicolumn{7}{|c|}{01608500 South Branch Potomac River near Springfield } \\
\hline Annual & 763 & 696 & 757 & 612 & 864 & 807 \\
\hline Winter & 1,230 & 1,080 & 1,270 & 1,080 & 1,380 & 1,260 \\
\hline Spring & 1,050 & 1,020 & 1,060 & 860 & 1,020 & 1,110 \\
\hline Summer & 283 & 285 & 270 & 141 & 317 & 321 \\
\hline Fall & 492 & 393 & 426 & 370 & 741 & 534 \\
\hline \multicolumn{7}{|c|}{01611500 Cacapon River near Great Cacapon } \\
\hline Annual & 329 & 286 & 325 & 275 & 401 & 343 \\
\hline Winter & 528 & 442 & 542 & 484 & 626 & 536 \\
\hline Spring & 462 & 431 & 468 & 386 & 479 & 490 \\
\hline Summer & 113 & 102 & 112 & 73 & 162 & 112 \\
\hline Fall & 214 & 168 & 179 & 155 & 339 & 236 \\
\hline \multicolumn{7}{|c|}{01636500 Shenandoah River at Millville } \\
\hline Annual & 1,750 & 1,580 & 1,680 & 1,320 & 2,050 & 1,900 \\
\hline Winter & 2,520 & 2,190 & 2,400 & 2,230 & 2,980 & 2,700 \\
\hline Spring & 2,230 & 2,050 & 2,220 & 1,670 & 2,260 & 2,500 \\
\hline Summer & 922 & 904 & 914 & 533 & 1,110 & 977 \\
\hline Fall & 1,320 & 1,170 & 1,190 & 837 & 1,840 & 1,440 \\
\hline \multicolumn{7}{|c|}{03051000 Tygart Valley River at Belington } \\
\hline Annual & 355 & 323 & 351 & 310 & 400 & 369 \\
\hline Winter & 612 & 582 & 642 & 555 & 649 & 605 \\
\hline Spring & 423 & 399 & 412 & 391 & 433 & 452 \\
\hline Summer & 105 & 87 & 112 & 43 & 118 & 122 \\
\hline Fall & 278 & 223 & 239 & 252 & 401 & 299 \\
\hline \multicolumn{7}{|c|}{03053500 Buckhannon River at Hall } \\
\hline Annual & 290 & 256 & 292 & 250 & 319 & 308 \\
\hline Winter & 506 & 463 & 542 & 436 & 528 & 510 \\
\hline Spring & 319 & 302 & 303 & 298 & 314 & 352 \\
\hline Summer & 88.2 & 69.1 & 95.3 & 40.9 & 104 & 100 \\
\hline Fall & 248 & 188 & 230 & 224 & 330 & 270 \\
\hline
\end{tabular}


Appendix 1. Annual and seasonal base flows at 15 streamflow-gaging stations in West Virginia, 1930-2002.—Continued

[Winter, January 1-March 31; spring, April 1-June 30; summer, July 1-September 30; fall, October 1-December 31]

\begin{tabular}{|c|c|c|c|c|c|c|}
\hline \multirow{2}{*}{ Season } & \multicolumn{6}{|c|}{ Base flow for the indicated period, in cubic feet per second } \\
\hline & 1930-2002 & $1930-42$ & $1943-62$ & $1963-69$ & 1970-79 & 1980-2002 \\
\hline \multicolumn{7}{|c|}{03061500 Buffalo Creek at Barrackville } \\
\hline Annual & 67 & 56 & 63 & 50 & 83 & 73 \\
\hline Winter & 128 & 124 & 126 & 92 & 147 & 134 \\
\hline Spring & 78 & 61 & 68 & 79 & 89 & 88 \\
\hline Summer & 16 & 9.1 & 16 & 5.4 & 25 & 18 \\
\hline Fall & 45 & 29 & 42 & 22 & 72 & 51 \\
\hline \multicolumn{7}{|c|}{03066000 Blackwater River at Davis } \\
\hline Annual & 111 & 95 & 109 & 106 & 120 & 118 \\
\hline Winter & 179 & 148 & 189 & 186 & 190 & 180 \\
\hline Spring & 131 & 119 & 131 & 125 & 126 & 141 \\
\hline Summer & 40 & 39 & 37 & 25 & 43 & 48 \\
\hline Fall & 92 & 76 & 79 & 87 & 121 & 102 \\
\hline \multicolumn{7}{|c|}{03069500 Cheat River near Parsons } \\
\hline Annual & 811 & 709 & 825 & 727 & 882 & 851 \\
\hline Winter & 1,230 & 1,070 & 1,340 & 1,130 & 1,290 & 1,240 \\
\hline Spring & 1,020 & 934 & 1,050 & 950 & 1,040 & 1,070 \\
\hline Summer & 319 & 289 & 322 & 188 & 344 & 361 \\
\hline Fall & 670 & 540 & 586 & 641 & 859 & 743 \\
\hline \multicolumn{7}{|c|}{03070500 Big Sandy Creek at Rockville } \\
\hline Annual & 214 & 187 & 213 & 186 & 249 & 224 \\
\hline Winter & 367 & 336 & 379 & 340 & 401 & 367 \\
\hline Spring & 258 & 230 & 257 & 253 & 269 & 273 \\
\hline Summer & 56 & 48 & 58 & 14 & 81 & 60 \\
\hline Fall & 175 & 133 & 157 & 135 & 246 & 196 \\
\hline \multicolumn{7}{|c|}{03182500 Greenbrier River at Buckeye } \\
\hline Annual & 432 & 402 & 440 & 374 & 479 & 437 \\
\hline Winter & 754 & 733 & 788 & 672 & 823 & 732 \\
\hline Spring & 537 & 484 & 561 & 511 & 523 & 558 \\
\hline Summer & 123 & 127 & 127 & 53 & 136 & 132 \\
\hline Fall & 312 & 264 & 284 & 260 & 433 & 326 \\
\hline \multicolumn{7}{|c|}{03183500 Greenbrier River at Alderson } \\
\hline Annual & 919 & 818 & 922 & 781 & 1,017 & 974 \\
\hline Winter & 1,590 & 1,400 & 1,650 & 1,370 & 1,710 & 1,660 \\
\hline Spring & 1,190 & 1,080 & 1,200 & 1,080 & 1,150 & 1,280 \\
\hline Summer & 284 & 320 & 277 & 138 & 330 & 295 \\
\hline Fall & 616 & 471 & 560 & 530 & 880 & 660 \\
\hline
\end{tabular}


Appendix 1. Annual and seasonal base flows at 15 streamflow-gaging stations in West Virginia, 1930-2002.-Continued

[Winter, January 1-March 31; spring, April 1-June 30; summer, July 1-September 30; fall, October 1-December 31]

\begin{tabular}{|c|c|c|c|c|c|c|}
\hline \multirow{2}{*}{ Season } & \multicolumn{6}{|c|}{ Base flow for the indicated period, in cubic feet per second } \\
\hline & 1930-2002 & $1930-42$ & $1943-62$ & $1963-69$ & $1970-79$ & 1980-2002 \\
\hline \multicolumn{7}{|c|}{03186500 Williams River at Dyer } \\
\hline Annual & 173 & 165 & 171 & 153 & 190 & 176 \\
\hline Winter & 284 & 295 & 293 & 255 & 297 & 272 \\
\hline Spring & 201 & 173 & 207 & 184 & 204 & 214 \\
\hline Summer & 57 & 56 & 55 & 29 & 66 & 65 \\
\hline Fall & 149 & 136 & 130 & 144 & 192 & 155 \\
\hline \multicolumn{7}{|c|}{03198500 Big Coal River at Ashford } \\
\hline Annual & 278 & 211 & 274 & 240 & 325 & 306 \\
\hline Winter & 530 & 430 & 561 & 461 & 610 & 540 \\
\hline Spring & 349 & 275 & 334 & 287 & 358 & 415 \\
\hline Summer & 77 & 62 & 57 & 56 & 94 & 101 \\
\hline Fall & 155 & 77 & 143 & 156 & 238 & 170 \\
\hline \multicolumn{7}{|c|}{03214000 Tug Fork near Kermit and 03214500 Tug Fork at Kermit } \\
\hline Annual & 744 & 561 & 719 & 679 & 923 & 814 \\
\hline Winter & 1,350 & 977 & 1,400 & 1,220 & 1,640 & 1,420 \\
\hline Spring & 248 & 211 & 236 & 218 & 281 & 1,140 \\
\hline Summer & 246 & 223 & 211 & 208 & 299 & 318 \\
\hline Fall & 98 & 50 & 81 & 105 & 156 & 380 \\
\hline
\end{tabular}


For additional information call or write to:

Director, U.S. Geological Survey

West Virginia Water Science Center

11 Dunbar Street,

Charleston, WV 25301

http://wv.usgs.gov 
흘.

อั

음

罚

끙

के

悉

蛋

s

勇

言

$\infty$

.

尺.

艿

局

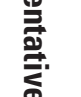

$\stackrel{\circ}{\circ}$

总

芯

於

$\stackrel{\$}{9}$

5

is

s

蛋.

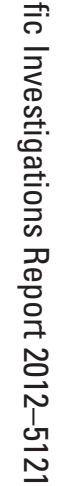

